\title{
A study of inactivation of Chlamydia trachomatis by normal human serum
}

\author{
A P JOHNSON,* M F OSBORN,* S ROWNTREE, † B J THOMAS, * AND \\ D TAYLOR-ROBINSON*
} From the *Division of Communicable Diseases and the +Division of Immunological Medicine,
MRC Clinical Research Centre, Harrow, Middlesex

SUMMARY To assess the effect of human serum on the viability of Chlamydia trachomatis, organisms were mixed with unheated and heat inactivated homologous serum, and the numbers surviving after incubation at $37^{\circ} \mathrm{C}$ for 1 hour were compared. With a pool of sera obtained from 12 donors, the number of chlamydiae surviving incubation in unheated serum was less than $1 \%$ of that surviving incubation in heat inactivated serum. The antichlamydial activity of the unheated pooled serum samples could be noticeably reduced by treatment with Mg-EGTA (ethyleneglycolbis ( $\beta$-amino ethyl ether)-N, $N^{\prime}$-tetra-acetic acid). This indicated a requirement for calcium ions and showed that the alternative pathway of complement activation played only a minor role, if any, in the inactivation process. When 12 serum samples were tested individually it was found that four inactivated chlamydiae to an extent comparable with that seen with the pooled serum. The other eight samples showed only moderate (or slight) antichlamydial activity, with survival rates in unheated serum of $20-60 \%$ (or more than $60 \%$ ) of those in heat inactivated serum. There was no correlation between the titres of antichlamydial antibodies and antichlamydial activity, all serum samples having undetectable or low concentrations of antibody on measurement by microimmunofluorescence. The antichlamydial activity destroyed by heating was restored, however, when heat inactivated serum was mixed with an equal volume of an unheated serum that was not inhibitory to chlamydiae. When the latter serum was heated before addition antichlamydial activity was not restored, indicating the requirement of both a heat stable and a heat labile factor. This observation and the need for calcium ions for inactivation of chlamydiae are compatable with killing mediated by antibody and complement. Thus serum samples from individuals with no clinical or serological evidence of infection with chlamydiae vary in their ability to inactivate the organism, some having antichlamydial activity which is possibly mediated by antibody and complement.

\section{Introduction}

Although Chlamydia trachomatis is an important human pathogen, ${ }^{1}$ little is known of the factors that determine its pathogenicity. The virulence of many micro-organisms is determined by their surface structure, with cell wall or capsular antigens acting to promote colonisation or to resist host defence mechanisms. ${ }^{2}$ The cell wall of $C$ trachomatis is

Address for reprints: Dr A P Johnson, Division of Communicable Diseases, MRC Clinical Research Centre, Watford Road, Harrow, Middlesex HA1 3UJ

Accepted for publication 2 May 1983 structurally and chemically similar to that of Gram negative bacteria, with an inner cytoplasmic membrane surrounded by a trilaminar outer membrane. ${ }^{3}$ All Chlamydia spp also contain a group antigen consisting of lipopolysaccharide, the immunodominant determinant of which is similar to, but not identical with, 2-keto-3-deoxyoctanoic acid from salmonella lipopolysaccharide. ${ }^{4}$ Some strains of Gram negative bacteria are susceptible to the bactericidal activity of normal human serum which may be mediated by antibody and complement, although bacterial lipopolysaccharide may activate the alternative complement pathway in the absence of antibody. ${ }^{5}$ In view of the similarity between the 
cell walls of $C$ trachomatis and of Gram negative bacteria, we investigated the effect of normal human serum on the viability of chlamydiae with particular regard to the possible role of the classic and alternative complement pathways, as activation of complement by either mechanism may contribute to immunity from chlamydial infection and development of disease.

\section{Materials and methods}

\section{CHLAMYDIA TRACHOMATIS}

A strain of $C$ trachomatis designated 6234 was used. It had been isolated from the urethra of a patient with non-gonococcal urethritis and was passed four times in McCoy cells treated with cycloheximide ${ }^{6}$ before being stored in liquid nitrogen in sucrose phosphate medium (2SP) containing 10\% heat inactivated fetal calf serum.

\section{SERUM SAMPLES}

Blood samples were obtained by venepuncture from volunteers on the staff of the Clinical Research Centre after approval had been given by the Ethics Committee. This group of subjects was chosen in the expectation that most of the serum samples would have low or undetectable titres of chlamydial antibodies. Each blood sample was allowed to clot for about 1 hour at room temperature and the serum was separated by centrifugation and stored in small volumes at $-70^{\circ} \mathrm{C}$. Complement assays (kindly performed by Mrs R Hill, Division of Immunological Medicine, CRC) showed that all the serum samples had normal levels of haemolytic complement activity.

In preliminary experiments a pool containing serum from 12 donors was used. Such pooled samples have been used previously to study the sensitivity to serum of another genital pathogen, Neisseria gonorrhoeae. ${ }^{7}$ In later experiments serum samples from 12 individual donors, six of whom had contributed to the serum pool, were used separately.

\section{Mg-EGTA}

A stock solution of $100 \mathrm{mmol} / 1 \mathrm{Mg}$-EGTA (ethyleneglycol-bis ( $\beta$-amino ethyl ether)-N,N'-tetra-acetic acid) was prepared in physiological saline as described by Fine et al. ${ }^{8}$ Mg-EGTA selectively inhibits the classical pathway of complement activation by chelating calcium ions, but does not inhibit the alternative complement pathway.

\section{TEST SYSTEM}

To determine whether $C$ trachomatis organisms were inactivated by serum, $20 \mu \mathrm{l}$ of a chlamydial suspension were added to $150 \mu \mathrm{l}$ of serum supplemented with $30 \mu \mathrm{l}$ of either physiological saline or phosphate buffered saline (PBS). In some experiments the $30 \mu \mathrm{l}$ of saline were replaced by $20 \mu \mathrm{l}$ of the stock solution of Mg-EGTA with $10 \mu$ l of saline.

After addition of chlamydiae to the serum samples, the mixtures were incubated at $37^{\circ} \mathrm{C}$ for one hour. The number of viable chlamydiae in the mixtures at the end of the incubation period was determined by titration in McCoy cells treated with cycloheximide using centrifuge assisted inoculation. ${ }^{6}$ The cell monolayers were coded before microscopic examination to avoid subjective bias. Inactivation of chlamydiae was assessed at the end of the incubation period by comparing the number of viable chlamydiae in unheated serum with the number in homologous serum that had previously been heated at $56^{\circ} \mathrm{C}$ for 30 minutes to inactivate complement.

\section{SEROLOGICAL TEST}

The presence of IgM and IgG antibodies to $C$ trachomatis in the serum samples was determined by microimmunofluorescence. ${ }^{9}$

\section{Results}

INACTIVATION OF C TRACHOMATIS BY POOLED HUMAN SERUM AND EFFECT OF ADDING Mg-EGTA

In six experiments, the results of one of which are shown in table $I$, the number of viable chlamydiae

TABLE I Survival of $C$ trachomatis after incubation at $37^{\circ} \mathrm{C}$ for 1 hour in unheated and heat inactivated pooled human serum with and without addition of Mg-EGTA

\begin{tabular}{ll}
\hline Treatment of serum & $\begin{array}{l}\text { No of chlamydiae } \\
\text { recovered }\end{array}$ \\
\hline Unheated & $2 \cdot 21$ \\
Heat inactivated & $4 \cdot 45$ \\
Unheated with $10 \mathrm{mmol} / 1 \mathrm{Mg}-\mathrm{EGTA}$ & $4 \cdot 32$ \\
Heat inactivated with $10 \mathrm{mmol} / \mathrm{Mg}$ - & $4 \cdot 61$ \\
$\quad$ EGTA & 4 \\
\hline
\end{tabular}

*Inclusion forming units/ml $\left(\log _{10}\right)$.

recovered after incubation in unheated serum was less than $1 \%$ of the number recovered after incubation in heat inactivated serum. The serum was supplemented with $10 \mathrm{mmol} / 1 \mathrm{Mg}$-EGTA in four experiments, in each of which the inactivation of chlamydiae by unheated serum was markedly inhibited. In two experiments the inactivation of chlamydiae was completely inhibited, while in the other two survival of the organisms in the Mg-EGTA treated unheated serum was about $70 \%$ of that in heat inactivated serum as opposed to less than $1 \%$ survival in the untreated serum (table I). This 
indicated that the inactivation of chlamydiae by serum predominantly involved the classical complement pathway, with only a possible minor contribution by the alternative complement pathway.

\section{ANTICHLAMYDIAL ACTIVITY AND TITRES OF CHLAMYDIAL ANTIBODY IN INDIVIDUAL SERUM SAMPLES}

In view of the inactivation of chlamydiae by pooled serum, we investigated the effect of individual serum samples on the viability of $C$ trachomatis. Of 12 serum samples, four inactivated chlamydiae to an extent comparable with that seen with pooled serum, whereas eight did so only slightly (figure). Survival of

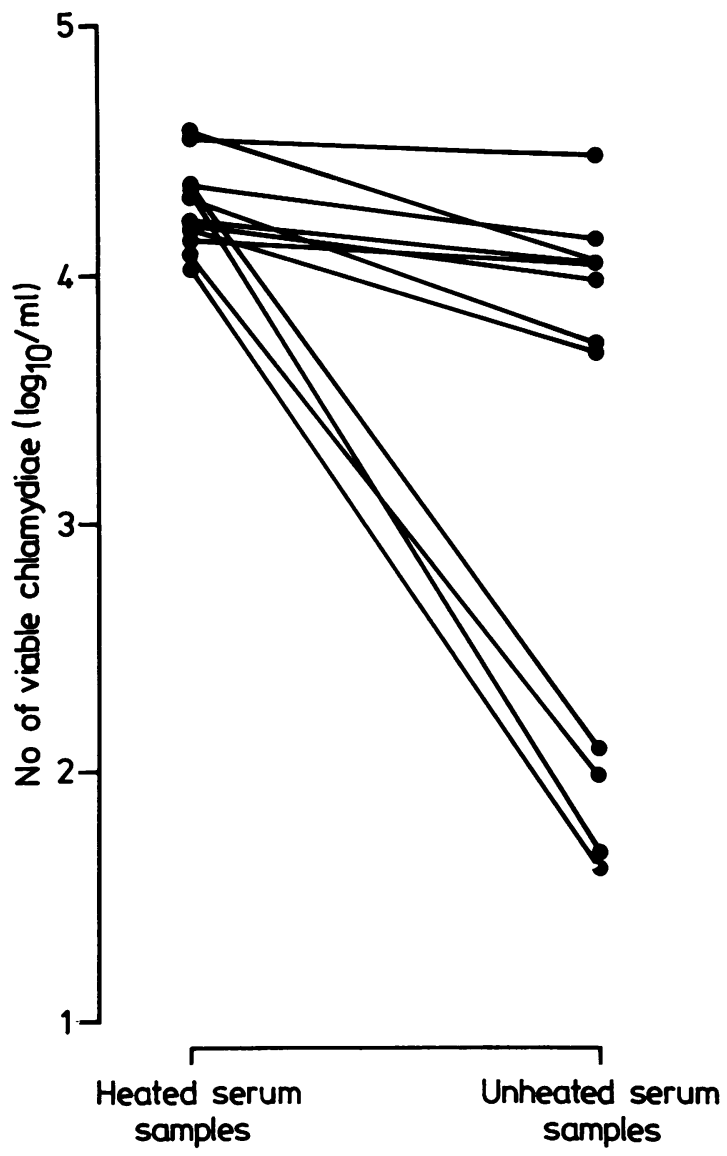

FIGURE Survival of chlamydiae in heat inactivated and unheated human serum samples after incubation at $37^{\circ} \mathrm{C}$ for 1 hour. Homologous heat inactivated and unheated serum samples are joined by lines. chlamydiae in three of these eight serum samples was generally $20-60 \%$ of that in heat inactivated homologous samples, while the other five generally allowed more than $60 \%$ of the survival rate in heat inactivated serum. There was, however, no correlation between the antichlamydial activity of the individual serum samples and the antibody titre measured by microimmunofluorescence (table II).

TABLE II Antichlamydial activity and antibody titres of individual human serum samples

\begin{tabular}{|c|c|c|c|}
\hline \multirow{2}{*}{$\begin{array}{l}\text { Serum } \\
\text { No }\end{array}$} & \multirow{2}{*}{$\begin{array}{l}\text { Antichlamydial } \\
\text { activity* }\end{array}$} & \multicolumn{2}{|c|}{$\begin{array}{l}\text { Titret of anti- } \\
\text { chlamydial antibody }\end{array}$} \\
\hline & & $I g M$ & $I g G$ \\
\hline 1 & slight $(>60 \%)$ & - & $1 / 1$ (F) \\
\hline 2 & slight $(>60 \%)$ & - & $1 / 1$ (F) \\
\hline 3 & slight $(>60 \%)$ & $1 / 1$ (F) & $1 / 2$ \\
\hline 4 & slight $(>60 \%)$ & - & \\
\hline 5 & slight $(>60 \%)$ & - & $1 / 8$ (F) \\
\hline 6 & moderate $(20-60 \%)$ & - & - \\
\hline 7 & moderate $(20-60 \%)$ & - & $1 / 1$ (F) \\
\hline 8 & moderate $(20-60 \%)$ & - & - \\
\hline 9 & great $(<2 \%)$ & - & - \\
\hline 10 & great $(<2 \%)$ & - & $1 / 2(F)$ \\
\hline 11 & great $(<2 \%)$ & - & $1 / 2$ \\
\hline 12 & great $(<2 \%)$ & $1 / 2$ & $1 / 2$ \\
\hline $\begin{array}{l}\text { *Survi } \\
\text { percen } \\
\text { †High } \\
\text { (F) }=\text { f }\end{array}$ & $\begin{array}{l}\text { hlamydiae in unh } \\
\text { rvival in heat inacti } \\
\text { n of serum showing } \\
\text { scence. }\end{array}$ & $\begin{array}{l}\text { um ex } \\
\text { nologou } \\
\text { nce. }\end{array}$ & as a \\
\hline
\end{tabular}

REQUIREMENT OF A HEAT LABILE SERUM FACTOR FOR INACTIVATION OF CHLAMYDIAE As described above, the ability of pooled human serum or of individual serum samples to inactivate chlamydiae was abolished by heating, thus suggesting a possible requirement for complement. This idea was supported by the observation that the antichlamydial activity of heat inactivated serum could be restored by adding an equal volume of an unheated serum that was not itself inhibitory to chlamydiae (table III). Furthermore, heating of the

TABLE III Survival of C trachomatis after incubation for 1 hour at $37^{\circ} \mathrm{C}$ in human serum

\begin{tabular}{|c|c|c|}
\hline Serum No* & $\begin{array}{l}\text { Treatment } \\
\text { of serum }\end{array}$ & $\begin{array}{l}\text { Not of } \\
\text { chlamydiae } \\
\text { recovered }\end{array}$ \\
\hline $\begin{array}{l}9 \\
9\end{array}$ & $\begin{array}{l}\text { unheated } \\
\text { heat inactivated }\end{array}$ & $\begin{array}{r}<1 \cdot 00 \\
4 \cdot 03\end{array}$ \\
\hline $\begin{array}{l}1 \\
1\end{array}$ & $\begin{array}{l}\text { unheated } \\
\text { heat inactivated }\end{array}$ & $\begin{array}{l}4 \cdot 06 \\
3 \cdot 99\end{array}$ \\
\hline $\begin{array}{l}9 \\
\text { plus } 1\end{array}$ & $\left.\begin{array}{l}\text { heat inactivated } \\
\text { unheated }\end{array}\right\}$ & $2 \cdot 20$ \\
\hline $\begin{array}{l}9 \\
\text { plus } 1\end{array}$ & $\left.\begin{array}{l}\text { heat inactivated } \\
\text { heat inactivated }\end{array}\right\}$ & $4 \cdot 03$ \\
\hline
\end{tabular}

* Refers to serum samples listed in table 2.

tInclusion forming units/ml $\left(\log _{10}\right)$. 
donor serum prior to the addition failed to restore the antichlamydial activity of the recipient heat inactivated serum. This showed that the inactivation of chlamydiae by serum required both a heat stable and a heat labile factor.

\section{Discussion}

The results presented here show that $C$ trachomatis is susceptible to inactivation by unheated human serum. The observation that this was markedly inhibited when calcium ions were chelated showed that the alternative complement pathway played at best only a minor role in the inactivation process. Inactivation mediated by serum required heat stable and heat labile factors and calcium ions, which suggests involvement of the classical complement pathway. Although there was no correlation between the antichlamydial activity of serum and the level of detectable antichlamydial antibody, this does not rule out the possibility of killing mediated by antibody. The antibody detected by microimmunofluorescence in serum samples that did not inactivate chlamydiae may have been directed against chlamydial antigens that did not function as efficient triggers of lysis mediated by complement. An example is seen with $\boldsymbol{N}$ gonorrhoeae where antibody to the lipopolysaccharide may kill the bacteria in the presence of complement, but antibodies to pili do not. ${ }^{10} \mathrm{~A}$ further consideration is that antibody responsible for complement activation may have been present at a concentration too low to be detected by microimmunofluorescence but was nevertheless capable of killing chlamydiae because of the amplification effect of the complement cascade. Serum samples that appear to lack antichlamydial antibody when assayed by microimmunofluorescence may contain antibody detectable by a more sensitive immunoelectrophoretic transfer method. ${ }^{11}$ A full understanding of the mechanism of serum inactivation of chlamydiae needs more information on the immunochemical and structural composition of the chlamydial cell surface, together with the application of sensitive assays for detecting antibodies directed against individual antigens.

In many serological studies chlamydial antibody titres of $<1 / 8$, measured by microimmunofluorescence, are regarded as normal. The results of this study, however, indicate that serum with such titres may inactivate chlamydiae. Whether this is important in terms of development of disease and immunity to infection remains to be determined.

\section{References}

1. Taylor-Robinson D, Thomas BJ. The role of Chlamydia trachomatis in genital-tract and associated diseases. J Clin Microbiol 1980; 33:205-33.

2. Smith H. Microbial surfaces in relation to pathogenicity. Bacteriological Reviews 1977;41:475-500.

3. Schachter J, Caldwell HD. Chlamydiae. Annu Rev Microbiol 1980;34:285-309.

4. Kuo C-C, Caldwell HD, Wang S-P, Grayston JT. Antigens of Chlamydia trachomatis. In: Hobson D, Holmes KK, eds. Nongonococcal urethritis and related infections. Washington DC: American Society for Microbiology, 1977;176-85.

5. Schreiber RD, Morrison DC, Podack ER, Müller-Eberhard HJ. Bactericidal activity of the alternative complement pathway generated from 11 isolated plasma proteins. J Exp Med 1979; 149:870-82.

6. Thomas BJ, Evans RT, Hutchinson GR, Taylor-Robinson D. Early detection of chlamydial inclusions combining the use of cycloheximide-treated McCoy cells and immunofluorescence staining. J Clin Microbiol 1977; 6:285-92.

7. Johnson AP, Osborn MF, Taylor-Robinson D. Iron-mediated protection of Neisseria gonorrhoeae against killing by normal human serum. FEMS Microbiol Letters 1978; 4:225-7.

8. Fine DP, Marney SR, Colley DG, Sergent JS, Des Prez RM. C3 shunt activation in human serum chelated with EGTA. $J$ Immunol 1972; 109:807-9.

9. Thomas BJ, Reeve P, Oriel JD. Simplified serological test for antibodies to Chlamydia trachomatis. J Clin Microbiol 1976;4:6-10.

10. Ward ME, Lambden PR, Heckels JE, Watt PJ. The surface properties of Neisseria gonorrhoeae: determinants of susceptibility to antibody complement killing. J Gen Microbiol 1978; 108:205-12.

11. Newhall WJ, Batteiger B, Jones RB. Analysis of the human serological response to proteins of Chlamydia trachomatis. Infect Immun 1982;38: 1181-9. 